\title{
PENDAMPINGAN USAHA GALERI ALNILAM MENUJU KEMANDIRIAN FINANSIAL MELALUI PENERAPAN SISTEM AKUNTANSI
}

\author{
Nurul Fatimah \\ nurul.fatimah@ekuitas.ac.id \\ Hana Fadhilah \\ hana_fadhilah22@yahoo.com \\ Annisa Nurfitriana \\ nurfitrianannisa09@gmail.com
}

SEKOLAH TINGGI ILMU EKONOMI (STIE) EKUITAS

\begin{abstract}
ABSTRAK
Pengabdian ini dilakukan di Galeri Alnilam yang merupakan salah satu usaha yang bergerak di bidang fashion. Kegiatan ini bertujuan untuk mewujudkan kemandirian keuangan Galeri Alnilam dalam menjalankan usahanya. Permasalahan yang dialami diantaranya ketergantungan pemasok, pengelolaan persediaan, pemasaran yang belum optimal, dan sistem akuntansi yang belum memadai. Metode yang digunakan dalam menyelesaikan permasalahanpermasalahan tersebut diawali dengan melakukan survei ke lokasi, tahap pelaksanaan dengan membeli kebutuhan usaha serta pembuatan sistem akuntansi, tahap terakhir yaitu tahap monitoring dan evaluasi. Kegiatan ini diharapkan dapat membantu Galeri Alnilam dalam peningkatan produktivitas, pengelolaan usaha dan keuangannya sehingga tercipta kemandirian secara finansial.
\end{abstract}

Kata kunci: Sistem Akuntansi, Usaha Kecil Menengah, Cimahi.

\section{PENDAHULUAN}

\subsection{Analisis Situasi}

Kegiatan pengabdian ini dilakukan pada sebuah usaha kecil baru yang bergerak di bidang penjualan busana dan perlengkapan muslimah bernama "Galeri Alnilam". Dikatakan baru karena usaha ini baru saja resmi memulai operasi usahanya sejak tanggal 9 November 2018 lalu. Berdasarkan observasi dan wawancara ke lokasi usaha, berikut uraian analisis proses bisnis Galeri Alnilam.
1.1.1 Sistem Pembelian dan Pengelolaan Persediaan

Galeri Alnilam melakukan usaha penjualan busana muslimah mulai dari kerudung, pakaian, alat sholat hingga aksesorisnya. Karena ini adalah perusahaan dagang, maka barang-barang tersebut tidak diproduksi sendiri melainkan membeli dari beberapa pemasok. Hingga saat ini (2 bulan sejak berdirinya), Galeri Alnilam baru memiliki satu pemasok yang sekaligus berperan sebagai investor.

Adapun sistem jual beli kepada pemasok bersifat konsinyasi. Jika ada persediaan barang yang tidak laku dijual 
maka akan dikembalikan kepada supplier. Dengan sistem ini sangat menguntungkan Galeri Alnilam sebagai perusahaan yang masih bertumbuh.

\subsubsection{Sistem Pemasaran}

Produk Galeri Alnilam dipasarkan dengan dua cara, yakni secara konvensional (offline) dan berbasis daring (online). Penjualan secara offline tidak hanya dilakukan oleh Ibu Neneng sebagai pemilik, tetapi juga dibantu oleh anggota keluarga lainnya secara menetap atau berkeliling (mobile). Sampai saat ini Ibu Neneng dibantu oleh 3 orang anggota keluarganya yang tengah bersekolah di SMA dan perguruan tinggi.

Pemasaran secara online dilakukan melalui media sosial whatsapp dan Instagram. Promosi melalui whatsapp sangat efektif dilakukan melalui status whatsapp dan pesan pribadi.

\subsubsection{Sistem Keuangan}

Hingga saat ini, pencatatan yang dilakukan oleh Galeri Alnilam masih sangat tradisional dan sederhana. Pemilik dan anggota tim lainnya mencatat penjualan dan pengeluaran pada grup whatsapp Galeri Alnilam secara harian. Cara ini efektif untuk mengontrol keluar masuknya uang dan barang di setiap hari namun belum cukup memadai untuk melihat kinerja usaha dalam periode yang lebih panjang.

\subsection{Permasalahan Mitra}

Berdasarkan uraian diatas, terdapat beberapa permasalahan penting yang perlu ditindaklanjuti, antara lain sebagai berikut:

\subsubsection{Permasalahan pembelian dan persediaan barang}

Dalam hal pembelian, kendala yang dihadapi oleh Galeri Alnilam sebagai perusahaan yang baru adalah ketergantungan yang sangat tinggi terhadap supply dari supplier (investor), sehingga penentuan barang yang akan dijual sangat dipengaruhi oleh supplier tersebut. Kendala lainnya yang dihadapi karena memiliki supplier tunggal dan berlokasi di luar kota adalah kesulitan untuk melakukan back order ketika ada permintaan spesifik dari konsumen.
Dalam hal penyimpanan barang dagangan, peralatan penyimpanan di Galeri Alnilam masih sangat minim. Barang yang sudah dibeli hanya disimpan di sebuah keranjang sederhana. Jika ada konsumen datang, barulah barang-barang tersebut dikeluarkan dari keranjang. Bagi konsumen yang proaktif, cara tersebut bukan masalah. Namun bagi konsumen yang pemalu atau malas, maka cara tersebut sangat tidak menyenangkan. Oleh karena itu Galeri Alnilam perlu memiliki rak atau gantungan untuk memajang barang dagangannya. Penggunaan boneka mannequin juga perlu untuk menunjukkan tampilan produk pada tubuh manusia.

\subsubsection{Permasalahan pemasaran}

Sejauh ini pemasaran yang efektif masih secara offline. Penjualan dari pemasaran online masih sangat jarang sehingga membuat pemilik yang juga sebagai admin akun Instagram @ galeri.alnilam kadang tidak semangat untuk melakukan pemotretan produk dan mengunggahnya ke Instagram. Sekalipun ada pesanan dari metode ini, rata-rata berasal dari pemasaran via whatsapp.

Pada metode offline juga sebenarnya pemasaran belum optimal karena belum tersedianya ruangan toko dan banner/ spanduk yang menunjukkan adanya Galeri Alnilam. Selama ini penjualan masih bersifat komunikasi personal dengan orangorang yang sudah kenal secara pribadi. Namun demikian orang asing yang melewati rumah pemilik tidak akan menyadari bahwa disana terdapat usaha toko busana muslimah.
1.2.3 Permasalahan Akuntansi/keuangan
Masalah akuntansi juga merupakan salah satu persoalan yang krusial bagi UKM Galeri Alnilam. Karena ketiadaan laporan keuangan yang baik menyebabkan manajemen tidak dapat mengetahui kinerja perusahaan secara berkesinambungan dan dalam rangka mengevaluasi apakan Galeri Alnilam dapat mandiri secara finansial dalam jangka waktu empat bulan kedepan. 


\section{METODOLOGI PELAKSANAAN}

2.1 Solusi yang Ditawarkan

Solusi dari permasalahan yang dihadapi oleh UKM Galeri Alnilam, diantaranya :

a. Mencari supplier lain yang lokasinya lebih dekat namun memiliki spesifikasi barang dan harga sama dengan yang ada saat ini.

b. Menyediakan tempat berupa rak dan etalase untuk menyimpan produk dan boneka mannequin untuk menampilkan contoh produk.

c. Diperlukan personil yang khusus melakukan pemotretan barang/ produk dan mengelola akun Instagram @ galeri.alnilam.

d. Diperlukan pengarahan dalam penentuan harga jual agar dapat bersaing dengan pasaran online.

e. Diperlukan ruangan toko dan spanduk untuk memaksimalkan promosi secara offline.

f. Adanya sistem akuntansi yang dapat membantu pelaku dalam melaporkan laporan keuangan usaha sehingga kendala keuangan dapat diatasi.

g. Diperlukan investor/ pemilik modal yang berkenan menanam modal dalam bentuk uang tunai sebagai modal kerja sehingga Galeri Alnilam tidak bergantung pada satu supplier saja.

\subsection{Mekanisme Pelaksanaan}

Berdasarkan permasalahan yang terjadi di Galeri Alnilam, berikut adalah metode yang dilaksanakan dalam pengabdian kepada masyarakat, yaitu:

a. Tahap Awal

Pada tahap awal, tim melakukan survei awal ke lokasi dan bertemu dengan pemilik, yaitu Ibu Neneng Dahlia. Dalam pertemuan tersebut, tim menjelaskan mengenai visi dan misi tim, yaitu dalam rangka tri dharma perguruan tinggi, dimana salah satunya adalah pengabdian kepada masyarakat, dan tim menjelaskan bantuan yang akan diberikan pada usaha Galeri Alnilam

b. Tahap Pelaksanaan

Dalam tahap pelaksanaan ini, pengabdian dilakukan degan beberap cara yaitu: membeli gantungan kerudung, rak kerudung, bonek mannequin, spanduk, dll, menyerahkan sejumlah uang untuk dijadikan modal kerja, dan membuat pembukuan sederhana dengan menggunakan excel

c. Tahap Terakhir

Pada tahapan ini tim melakukan monitoring dan evaluasi terhadap Galeri Alnilam. Bentuk monitoring berupa pendampingan penyusunan pembukuan Galeri Alnilam baik itu melalui tanya jawab secara langsung atau melalui media sosial terkait penyusunan pembukuan sistem akuntansi yang diterapkan. Pada tahapan ini diharapkan pelaku usaha mampu mandiri secara finansial.

\section{HASIL DAN LUARAN}

2.3 Pelaksanaan Pengabdian

Sebagaimana direncanakan sebelumnya bahwa untuk mengatasi kendala pemasaran kepada pelanggan yang berkunjung ke toko, kami menyumbangkan beberapa peralatan toko. Namun dalam pelaksanaannya, dikarenakan Galeri Alnilam juga masih sangat membutuhkan modal kerja untuk membiayai target penjualan di bulan Ramadhan, maka kami sepakat untuk mengambil alokasi anggaran peralatan. Dengan sumbangan berupa modal ini, Galeri Alnilam mampu melakukan pembelian secara mandiri dari supplier yang lebih dekat sehingga ongkos kirim bisa dihemat dan pemilihan barang dagangan pun lebih leluasa.

Beberapa peralatan yang disumbangkan ke Galeri Alnilam antara lain berupa:

1. Rak Pajangan

Digunakan untuk memajang barang dagangan berupa pakaian dan kerudung instan dan scarf dengan model gantungan dan susun. Secara total, terdapat 4 (empat) unit rak yang kami sumbangkan kepada UKM Galeri Alnilam. Dengan persediaan jumlah yang ada, sejauh ini dianggap cukup untuk memenuhi keperluan di Galeri Alnilam yang skala usahanya masih pada tahap berkembang. 


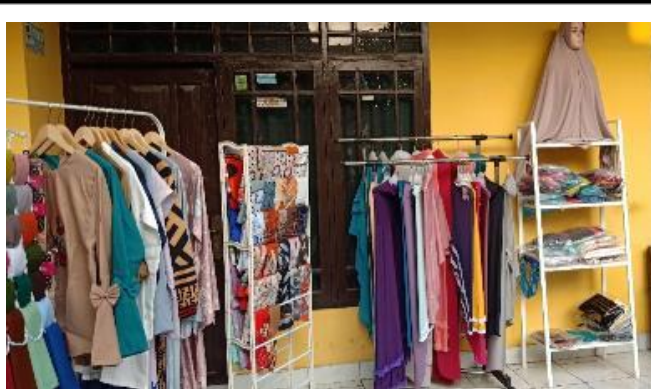

Gambar 3.1 Rak Gantung, Rak Susun Galeri Alnilam

2. Boneka Mannequin

Boneka mannequin digunakan untuk memeragakan penggunaan kerudung instan.

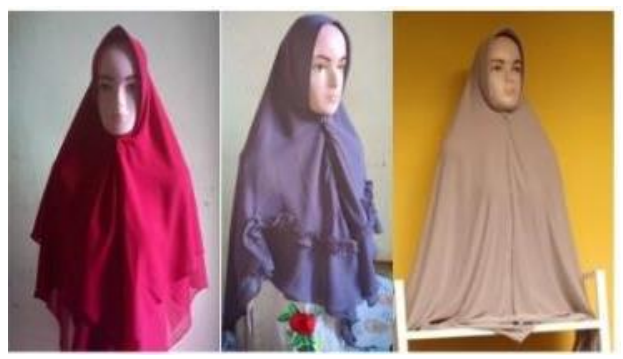

Gambar 3. 2 Boneka Mannequin di Galeri Alnilam

3. Box Penyimpanan

Box untuk menyimpan barang cacat, rusak atau sisa tidak laku terjual. Bentuk boks ini menyerupai keranjang serbaguna.

4. Spanduk

Spanduk yang dimaksud adalah tulisan dan logo Galeri Alnilam untuk disematkan di halaman toko sehingga warga sekitar yang berlalu lalang di halaman rumah mengenali usaha ini.

\subsection{Sistem Akuntansi}

Kontribusi pemikiran yang diberikan dengan membuat sistem pembukuan otomatis sederhana menggunakan software Microsoft Excel. Berikut uraian rinci dari aplikasi tersebut.

Program yang kami rancang ini hanya berupa sebuah file excel yang terdiri dari 7 sheets yang terintegrasi satu sama lainnya, yakni diantaranya :
1. Sheet 1 : Database Stok Barang

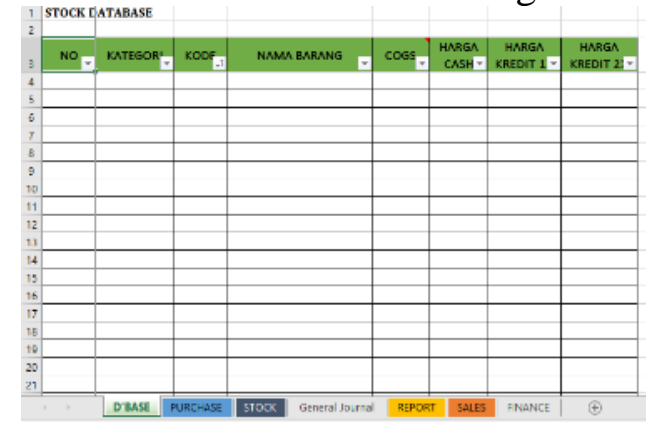

Gambar 3.3 Aplikasi Akuntansi Sheet 1: Stok Barang

Pada sheet pertama ini, dicantumkan data pokok dari produk-produk yang dijual seperti kode barang, harga jual dan harga pokok penjualan masing-masing produk. UKM Galeri Alnilam saat ini memiliki 8 (delapan) kategori produk, diantaranya bergo instan, blouse, celana, ciput, gamis, kaos kaki, kerudung, dan mukena. Sampai saat ini merk dan kode setiap barang dari 8 kategori tersebut sudah berjumlah 66 item.Untuk memudahkan identifikasi dari 66 produk tersebut maka pengkodean perlu dilakukan.

Kode barang dibuat dengan tujuan mengotomatisasi penginputan data transaksi setiap barang dengan cepat dan praktis ke setiap sheet lainnya dibandingkan harus mengetikkan nama barang secara lengkap. Pengkodean barang disini menggunakan sistem mnemonik, yakni menggabungkan empat huruf yang mewakili nama barangnya sesuai preferensi pemilik agar mudah diingat.

Selain harga jual, perlu juga dimasukkan data harga pokok penjualan (HPP), di aplikasi ini dicantumkan pada kolom COGS.Tujuannya agar pada akhir periode dapat diketahui berapa laba atau rugi yang diterima oleh UKM Galnilam. HPP produk pada usaha ini ditentukan dari harga beli yang diberikan oleh supplier. Setiap item produk memiliki HPP yang berbeda, oleh karenanya setiap barang dagangan baru masuk, pemilik harus menginputkan HPP dari setiap item barang secara teliti. 


\section{Sheet 2: Pembelian (Purchase)}

Lembar kedua ini menampilkan rincian jumlah dan jenis produk yang dibeli dari supplier. Langkah pengisian lembar ini sangat sederhana. Setiap kali pembelian dilakukan, pemilik tinggal menginputkan nomor (kolom A); tanggal (kolom B), kode barang (kolom C); dan kuantitas setiap varian produk (kolom E) secara manual. Adapun kolom nama barang (kolom D), harga (kolom F) dan HPP (kolom G) akan terisi otomatis dengan rumus ISBLANK dan VLOOKUP.

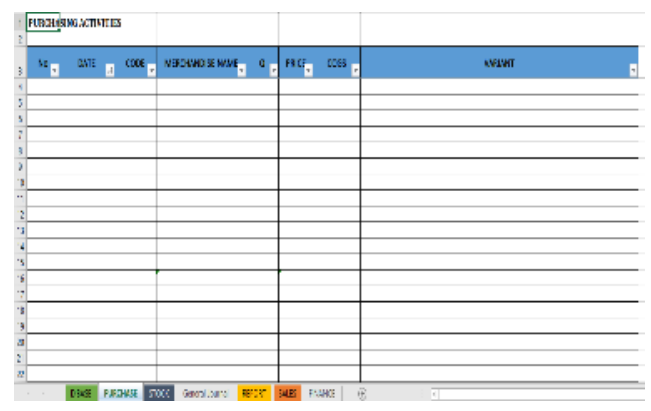

Gambar 3.4 Aplikasi Akuntansi Sheet 2: Pembelian

\section{Sheet 3: Penjualan}

Sheet 3 memiliki fungsi yang sama dengan jurnal penjualan, yakni bertujuan mencatat seluruh transaksi penjualan yang terjadi, baik secara tunai maupun kredit. Berdasarkan cara pemasarannya, kini Galeri Alnilam lebih mengutamakan penjualan secara offline yang sebagian besar pembayaran dilakukan secara kredit. Pemasaran secara online, masih dilakukan namun secara terbatas. Pada aplikasi ini, pemilik UKM tidak merasa perlu untuk membedakan jurnal penjualan berdasarkan metode pemasarannya, karena dirasa terlalu rumit. Oleh karena itu, semua penjualan diasumsikan bersifat tunai.

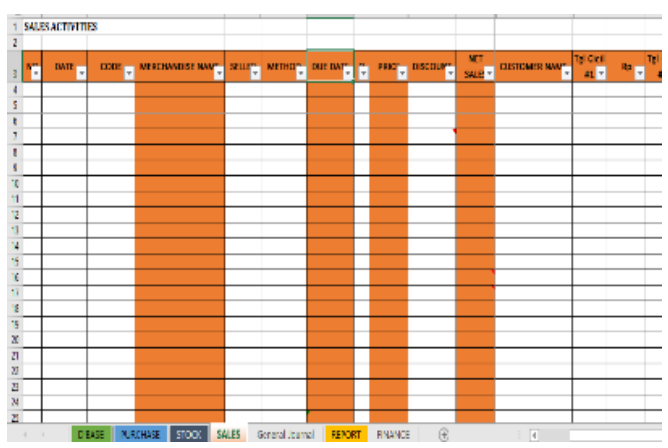

Gambar 3.5 Aplikasi Akuntansi Sheet3: Penjualan

Pada gambar diatas, pemilik UKM perlu menginput delapan kolom secara manual, yakni kolom-kolom berwarna putih. Sedangkan kolom-kolom yang berwarna merah akan otomatis terisi dengan menggunakan rumusstatistik.

\section{Sheet 4: Persediaan}

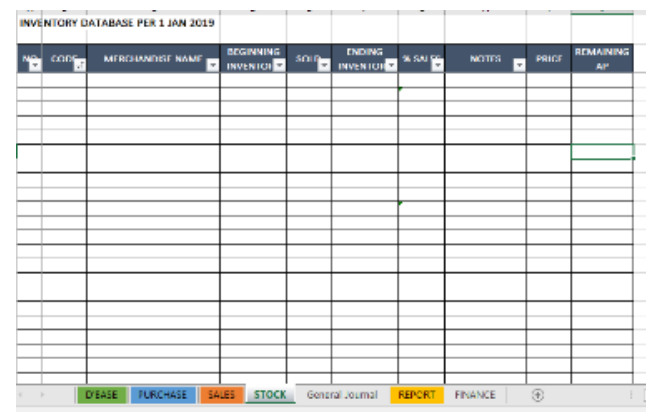

Gambar 3.6 Aplikasi Akuntansi Sheet 4: Persediaan Barang

Lembar ini dibuat dengan tujuan agar pemilik UKM dapat senantiasa memantau jumlah persediaan terkini tanpa harus menghitung secara fisik (stock opname), sehingga informasi ketersediaan barang dapat segera disampaikan kepada pelanggan. Efisiensi waktu dari aktivitas ini diharapkan dapat mempercepat proses pemenuhan pesanan dari pelanggan, sehingga pendapatan pun semakin cepat diperoleh.

Berdasarkan penuturan dari pemilik UKM, seringkali pesanan pelanggan baru dapat dikirim satu hari kemudian dikarenakan pemilik tidak memiliki perkiraan pasti berapa jumlah barang yang sudah hampir habis dan harus melakukan back order. 
Pada sheet keempat ini, pemilik tidak perlu menginputkan data secara manual, karena semua kolom sudah memiliki rumus statistik SUMIFS yang bersambung ke beberapa sheet sebelumnya.

\section{Sheet 5: Jurnal Umum}

Jurnal umum dimaksudkan agar pemilik mudah melacak saldo setiap akun untuk penyajian laporan keuangan secara terstandarisasi. Format dari jurnal umum ini sederhana, sesuai standar, yakni terdiri dari 4 kolom (tanggal, keterangan, debit, dan kredit).

Jurnal umum ini sudah mencakup buku besar, dengan menggunakan fungsi FILTER pada Microsoft Excel, pemilik dapat dengan mudah menyeleksi saldo setiap akun tanpa harus membuat buku besar masing-masing akun tersebut. Berikut ini tampilan dari jurnal umum yang dimaksud.

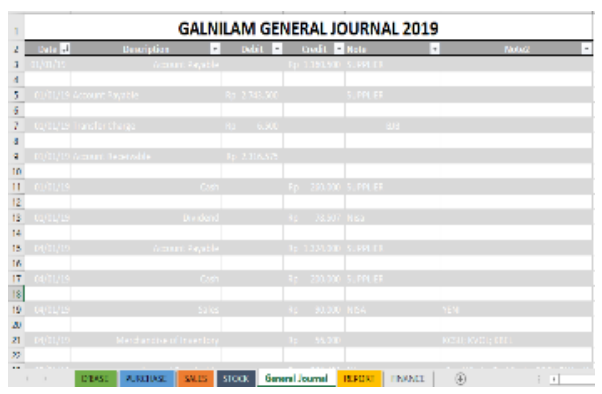

Gambar 3.7 Jurnal Umum Galeri Alnilam

\section{Sheet 6: Ringkasan Laporan}

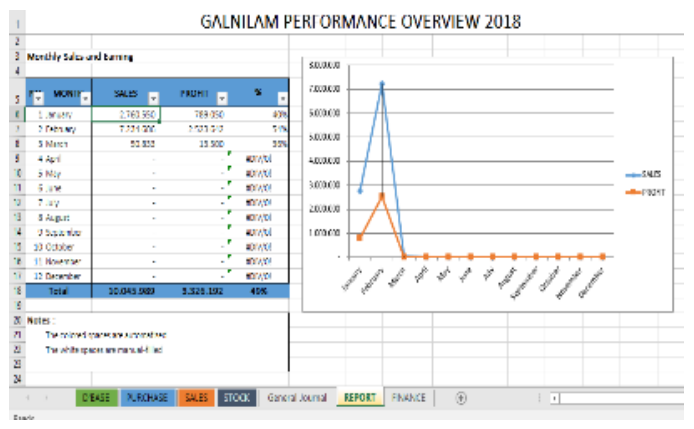

Gambar 3.8 Aplikasi Akuntansi Sheet 6: Laporan

Pada lembar ini pemilik akan dapat melihat secara keseluruhan performa penjualan dan laba yang diperoleh selama satu tahun. Angka pada kolom C dan D pada tabel ini akan terisi otomatis dengan link yang bersumber dari sheet 3. Sedangkan kolom $\mathrm{E}$ diisi dengan mempersentasikan angka pada kolom laba terhadap kolom penjualan.

Di sebelah kanan tabel ditampilkan sebuah grafik yang memvisualisasikan tren angka penjulan dan laba sepanjang tahun. Dengan begitu, pemilik akan lebih mudah menyimpulkan kinerja usahanya dari bulan ke bulan, apakah naik, turun atau stabil.

\section{Sheet 7: Keuangan (Finance)}

Lembar terakhir ini ditujukan untuk menampilkan proporsi pembagian hasil penjualan kepada setiap pihak, yakni pemilik dan investor setelah dikurangi berbagai keperluan seperti modal kerja dan donasi.

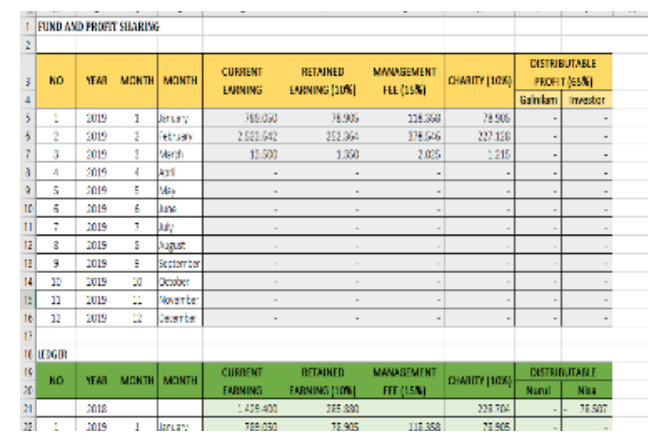

\section{Gambar 4.9 Sheet 7: Lembar Keuangan} Galeri Alnilam

Berdasarkan pendampingan yang telah dilakukan dalam penyusunan pembukuan tersebut, kami melihat bahwa Galeri Alnilam mengalami perkembangan yang cukup baik. Hal ini ditunjukkan dengan ditemukannya angka presisi keuntungan dan beban yang terjadi di setiap bulan. Disamping itu, alokasi profit kepada setiap staf marketing pun lebih objektif dan adil. Diharapkan pemilik UKM dapat menjaga konsistensi dalam melakukan pencatatan ini sehingga dalam jangka Panjang bisnis dapat mandiri sebagaimana diharapkan. 


\section{KESIMPULAN DAN SARAN}

Kesimpulan dari pengabdian ini yaitu:

1. Galeri Alnilam mampu meningkatan produktivitasnya dar ketersediaan pemasok

2. Galeri Alnilam mampu memasarkan produknya dengan peraltan dan sistem pemasaran yang mendukung

3. Galeri Alnilam mampu menyusun dan mengelola keuangan sehingga teripta kemandirian secara finansial.

\section{DAFTAR PUSTAKA}

Kieso, Donald E, dkk. 2011. Pengantar Akuntansi. Jakarta: Erlangga.

Kotler, Philip and Kevin Lane Keller. 2016. Marketing Management. $15^{\text {th }}$ Edition. New York. Prentice Hall. Pearson International edition.. 